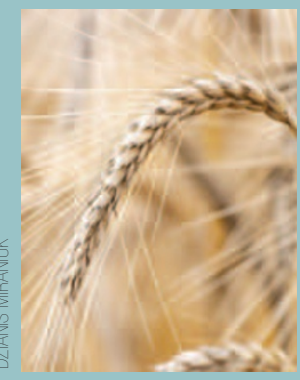

Cover design by Karen Moore

Nature Reports Climate Change

EDITORIAL OFFICE

Editor: Olive Heffernan

Assistant Editor/Copy Editor: Anna Barnett

Production Editor: Alexandra Hardy

Art Editor: Karen Moore

Web Production: Dennis Chu

\section{MANAGEMENT OFFICE}

Managing Director: Steven Inchcoombe

Publishing Director: David Swinbanks

Publisher: Jason Wilde

Editor in Chief, Nature Publications: Philip Campbell

Marketing Manager: Katy Dunningham

Managing Production Editor: Donald McDonald

Senior Production Editor: Derna Simpson

Senior Copy Editor: Jane Morris

Sponsorship Manager: Emma Green

Advertising Manager, Physical Sciences: Simon Allardice

The Macmillan Building, 4 Crinan St

London N1 9XW, UK

Tel: +44 (0) 2078334000

e-mail: nature@nature.com

VISIT NATURE REPORTS

CLIMATE CHANGE ONLINE

World Wide Web

http://www.nature.com/reports/climatechange

SUBSCRIPTIONS AND CUSTOMER SERVICES

For UK/Europe (excluding Japan):

Nature Publishing Group, Subscriptions, Brunel Road,

Basingstoke, Hants, RG21 6XS, UK.

Tel: +44 (0) 1256329242.

Subscriptions and customer services for

Americas - including Canada, Latin America and the

Caribbean: Nature Publishing Group,

Subscription Department, PO Box 5161, Brentwood,

TN 37024-5161.

Tel: (800) 5242688 (US) or 6158505315

(outside the US).

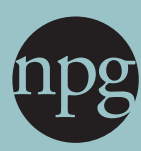

nature publishing group

nature

REPORTS climate change

the news behind the science, the science behind the news

\section{COUGHING UP THE CASH}

Whether we can avoid the worst consequences of climate change will ultimately be determined by whether we are willing to finance it.

Finding an effective means for financial assistance and investments to flow from north to south could be a make-or-break issue at the UN Climate Change Conference in Bali, Indonesia, where delegates from almost 190 nations have convened to agree on a road map for an international climate agreement to follow the Kyoto Protocol in 2012.

Nongovernmental organizations and delegates from the world's poorest nations, some of which are already beginning to experience the harsh affects of a warming climate, are calling on developed countries to boost funding to help these struggling nations adapt, and to transfer technology that will help them green their economies.

Under the Kyoto Protocol's Adaptation Fund, a paltry US\$163 million has been pledged by rich donor countries to developing nations, and just US\$67 million of this has actually been delivered. Yet the sum needed to finance adaptation and capacity-building in the south is in the region of several tens of billions of dollars, according the World Bank. Oxfam says that the very poorest nations also need an up-front payment of US\$1-2 billion immediately to address urgent adaptation needs.

The fund, which will finance projects such a building sea walls and irrigating crops, is currently derived from a two-percent levy on revenues generated by the Clean Development Mechanism, the scheme that allows industrialized nations to pay for carbon credits produced by emissions-reduction projects in the developing world and apply the credits against their own emissions targets back home. But it now looks as though the UN will have to expand its funding for adaptation, potentially through a direct tax on emissions.

The transfer of clean technologies to developing nations is another goal of the Kyoto Protocol that clearly has not been met. In part, this is owing to lack of funding from the public sector and lack of interest from the private sector, says Yvo De Boer, executive secretary of the UN Framework Convention on Climate Change.

The solution, says De Boer, will require the creation of investment potential through mechanisms such as the carbon market that can send a clear price signal to private investors, who are expected to fund $86 \%$ of future clean energy technology projects in the south. It will also require "intelligent financial engineering, to make public and private money go where it has never gone before" akin to "embarking on a Star Trek expedition", says De Boer.

A group of finance ministers is now thrashing out the details in side meetings at the Bali talks. By the end of the conference, it should be clear whether the world's richest nations are willing to cough up their portion of the much needed cash.
RESEARCH HIGHLIGHTS

\section{Cryosphere}

Summertime snowmelt

Alex Thompson

Palaoclimate

Cod on ice

Anna Barnett

Climate impacts

Late leaf fall

Alex Thompson

Earth science

Sizing up the sink

Anna Barnett

3

Biodiversity and ecology

Aphid outbreaks

Alicia Newton

\section{NEWS FEATURE}

4 What's next for the IPCC? Amanda Leigh Haag

\section{COMMENTARY}

\section{Comparing apples} with oranges

Richard Betts

\section{FOCUS FEATURE}

9 The backlash against biofuels

Kurt Kleiner

\section{B00KS \& ARTS}

12 The significance of small things

Gavin Schmidt

\section{NEWS \& VIEWS}

13 Slush find

Alan J. Kaufman 